\title{
Spatial and temporal resolution of carbon fluxes in a shallow coastal ecosystem, the Kattegat
}

\author{
Jacob Carstensen ${ }^{1, *}$, Daniel Conley ${ }^{1}$, Bärbel Müller-Karulis ${ }^{2}$ \\ ${ }^{1}$ Department of Marine Ecology, National Environmental Research Institute, PO Box 358, 4000 Roskilde, Denmark \\ ${ }^{2}$ University of Latvia, 6 Daugavgrivas St., 1007 Riga, Latvia
}

\begin{abstract}
Spatial and temporal variations in pelagic carbon fluxes were examined by means of a large-scale and long-term monitoring data set from the Kattegat, a shallow marginal sea impacted by man-induced eutrophication. Flows of carbon, nitrogen and phosphorus in the upper mixed layer $(0$ to $10 \mathrm{~m}$ ) were estimated from a simple descriptive model using measurements of primary production, temperature, and phytoplankton/zooplankton biomass as input variables. For all years combined, annual primary production at coastal stations $\left(171 \mathrm{~g} \mathrm{C} \mathrm{m}^{-2} \mathrm{yr}^{-1} ; 8\right.$ stations) was almost twice that at the deeper open-water stations (105 $\mathrm{g} \mathrm{C} \mathrm{m}^{-2} \mathrm{yr}^{-1} ; 5$ stations), which resulted in an annual primary production of $116 \mathrm{~g} \mathrm{C} \mathrm{m}^{-2} \mathrm{yr}^{-1}$ for the region as a whole during the entire study period (1989 to 1997). Interannual variation in primary production was substantially smaller than the between-station variation. The phytoplankton spring bloom contributed substantially to annual production (10 to $20 \%$ ), but the magnitude and timing were highly variable between years. Respiration accounted for on average $12 \%$ of the measured primary production. Annual sedimentation was estimated at $55 \mathrm{~g} \mathrm{C} \mathrm{m}^{-2}$ $\mathrm{yr}^{-1}$, equivalent to $54 \%$ of net primary production. The estimated new production was significantly related to nitrogen loading from the land and atmosphere, and a regression analysis predicted declines of between 20 and $47 \%$ in annual net primary production from a $50 \%$ reduction in nitrogen loading. Carbon and nutrient fluxes are consistent with those of earlier studies from the Kattegat based on small-scale and short-term data sets. However, combining monitoring data with a budget model greatly improved data resolution in both time and space. Estimated C/N/P fluxes from the model can act as reliable indicators for assessing the state of eutrophication in the Kattegat and other inland seas impacted by man-induced nutrient loading.
\end{abstract}

KEY WORDS: Primary production · Respiration $\cdot$ Sedimentation $\cdot$ Budget models $\cdot$ Monitoring data · Eutrophication $\cdot$ Kattegat

\section{INTRODUCTION}

Carbon fluxes have been investigated for a variety of ecosystems using different approaches, largely determined by the objective of the study, the availability of data and the characteristics of the studied ecosystem. Net ecosystem metabolism (production-respiration) appears to be a common focus for several riverine and estuarine studies, and it is assessed by means of budgets for carbon and nutrients (Howarth et al. 1996, Kemp et al. 1997, Smith \& Hollibaugh 1997). Oceanic studies of carbon fluxes have been concerned with the production and export of organic carbon. Wefer \&
Fischer (1991) reported large spatial variability in annual primary production and export fluxes in the Southern Ocean using sediment trap data, consistent with the variations documented in Fischer et al. (2000). The latter used satellite radiometer data and a global equation estimating the water-column-integrated primary production under various environmental conditions (Antoine \& Morel 1996). Bury et al. (2001) calculated production and export rates using ${ }^{15} \mathrm{~N}, \mathrm{NO}_{\mathrm{x}}$ chemiluminescence and ${ }^{14} \mathrm{C}$ methods during a phytoplankton spring bloom in the North Atlantic, and they documented a short-term decoupling in the ratio between carbon and nitrogen uptake rates based on 
Redfield ratios. This decoupling was explained by differences in protein synthesis during the bloom; however, the ratio of $\mathrm{C} / \mathrm{N}$ uptake was on average close to Redfield ratios. Koeve (2001) assessed new production from wintertime nutrient concentrations in the temperate and subarctic North Atlantic, which exhibited small interannual variability. Reigstad et al. (2000), on the other hand, documented large interannual differences in organic carbon export rates from sediment traps deployed in 3 Norwegian fjords, and they attributed these to changes in oceanic-coastal coupling. Carbon fluxes have also been assessed from a variety of modelling approaches not tied to any specific ecosystem, e.g. the coagulation model (Jackson 2001), the 1-dimensional numerical food web model (Walsh et al. 2001) and the trophic-transfer model (Iverson 1990). Most of the carbon flux studies described above are concerned with either spatial or temporal variability. However, both of these are important for assessing carbon fluxes in coastal ecosystems.

Primary production is the key process in assessing eutrophication (Nixon 1995). In the Kattegat, a shallow marginal sea bordered by Sweden and Denmark, levels of primary production are estimated to have increased by more than 2-fold since the 1950s (Richardson \& Heilmann 1995), and this has largely been attributed to man-induced increases in nitrogen loading from both land and atmospheric sources. Symptoms of eutrophication have become clearly visible and include loss of submerged aquatic vegetation (SandJensen et al. 1994), oxygen depletion (Andersson 1996) and changes in benthic faunal diversity (Rosenberg et al. 1992). These symptoms are believed to be related to the changes in primary production and consequently indirectly related to nitrogen loading (Rydberg et al. 1990), because nitrogen limits primary production in the Kattegat (Granéli 1987, Granéli et al. 1990). Nitrogen loads show large interannual fluctuations, which presumably lead to similar variations in primary production.

Sedimentation of organic material from the euphotic zone can potentially lead to oxygen deficiency in bottom waters (Falkowski et al. 1988, Wassmann 1991). The complex coupling between these processes is, however, poorly quantified (Olesen \& Lundsgaard 1995). In the Kattegat, this aspect has mainly been investigated in experimental studies by using sediment traps at short time intervals at single stations (Rydberg et al. 1990, Richardson \& Christoffersen 1991, Olesen \& Lundsgaard 1995). However, it cannot be automatically assumed that such data sets provide sufficient resolution in space and time for a projected, longerterm assessment of regional eutrophication.

The Danish National Aquatic Monitoring and Assessment Program (DNAMAP) was established in 1989 to monitor nutrient loading and ecological responses to governmental measures taken to reduce total nitrogen and total phosphorus loads by 50 and $80 \%$, respectively (Kronvang et al. 1993). DNAMAP was organised with the aim of obtaining information on a wide range of indicators of eutrophication (e.g. winter nutrient concentrations, summer chlorophyll a [chl a] concentrations) covering many estuaries and coastal zones in Denmark. This complements the Swedish national monitoring program, making the Kattegat one of the most extensively studied marginal seas in the world. Nevertheless, the time resolution of measurements at most stations on their own remains too coarse to quantitatively assess regional fluxes of carbon, nitrogen and phosphorus.

Linear interpolation in time is a common approach to generate higher frequency in data, but it can produce dubious results if sampling intensity is too low relative to the frequencies and magnitude of variations in the monitored processes (Chatfield 1984). For this reason, we used a combined large-scale (13 stations) and longterm (9 yr) data set which incorporated distinct geographic localities covering much of the Kattegat. This allowed us to fill gaps in some station-specific time series with predictions from a general linear model, taking into account data from all other stations. This approach seems justified by the fact that the key factors controlling pelagic processes in the Kattegat (meteorological variations and anthropogenic nutrient loading; Sehested Hansen et al. 1995) act on a regional scale, and as a result, monitoring data should show substantial temporal and spatial correlations.

In this paper, partly estimated time series were used as input to a budget model which quantifies the fate of primary production in the upper mixed layer. The objective of the study was to extract information from a large monitoring data set to assess carbon fluxes on a long-term and large spatial scale. The model predicts phytoplankton production and losses in terms of carbon fluxes. Integrating these processes over time and space provides yearly indications of eutrophication in the Kattegat as a whole. In addition, annual primary production rates were linked to external inputs of nutrients for the upper mixed layer in the Kattegat. Finally, we carried out a detailed comparison between these large-scale and long-term budgets and those reported in earlier studies based on less extensive data sets.

\section{STUDY AREA}

The Kattegat is a shallow transition area with estuarine character, located between the saline North Sea/ Skagerrak and the brackish Baltic Sea (Fig. 1), having 


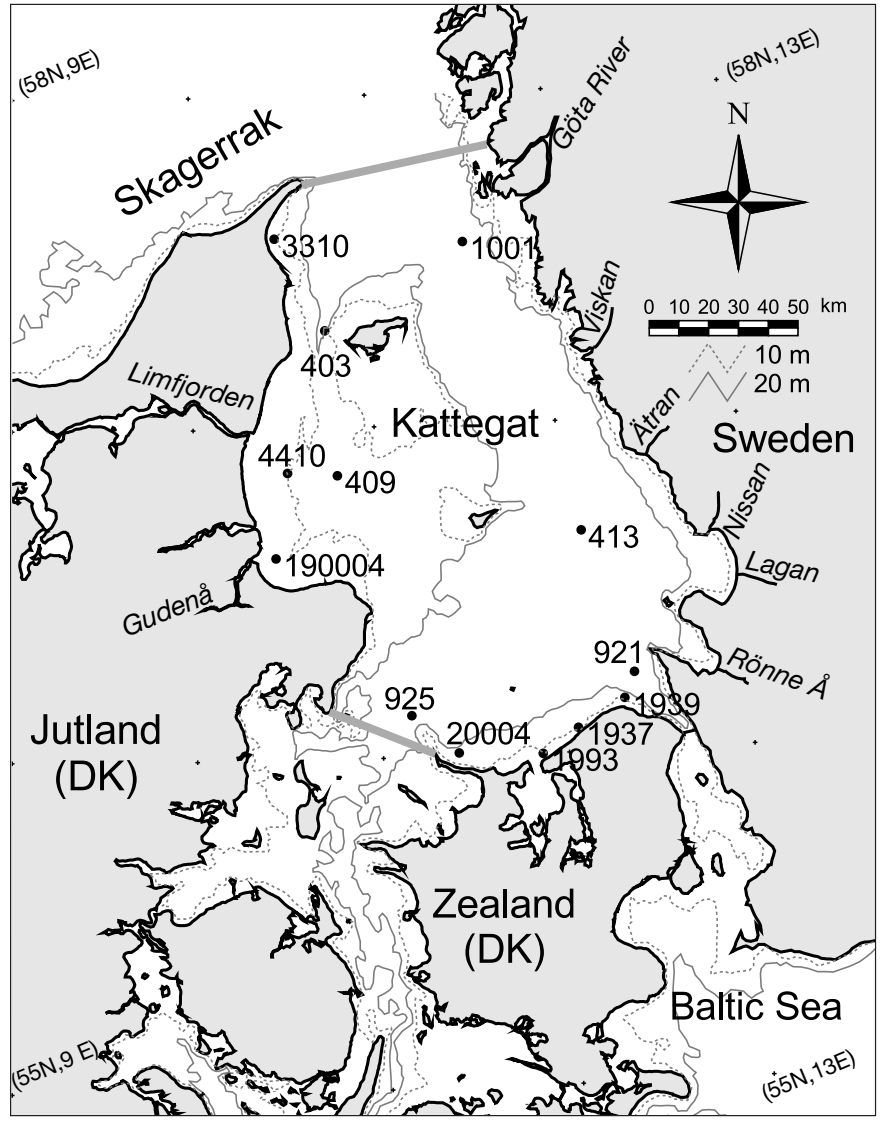

Fig. 1. Kattegat and adjoining seas with identification of monitoring stations used in the present study and depth contours. Major tributaries to the Kattegat are shown along the Swedish and Danish coasts. The boundaries of the Kattegat are marked by lightly shaded lines

a surface area, volume and average depth of $22290 \mathrm{~km}^{2}$, $533 \mathrm{~km}^{3}$ and $23.9 \mathrm{~m}$, respectively (Gustafsson 2000). Circulation is dominated by north-flowing surface water with a salinity gradient of 15 to $30 \mathrm{psu}$, and south-flowing deep water with salinities around 30 to $34 \mathrm{psu}$. The water column is considered to be almost permanently stratified, with a halocline located at ca $15 \mathrm{~m}$ depth (Andersson \& Rydberg 1988). The external loading of total nitrogen from land and atmosphere was on average $69 \times 10^{6} \mathrm{~kg} \mathrm{~N} \mathrm{yr}^{-1}$ for the period 1989 to 1997 , with large inter-annual and seasonal variations. Nitrogen transport from the nutrient-rich bottom water across the halocline is dominated by winddriven upward entrainment (Gustafsson 2000).

The Kattegat is characterised by a coastal shelf $<20 \mathrm{~m}$ deep in the western part, and a trench in the eastern part, where outflow from the Baltic Sea dominates (Fig. 1). Major tributaries to the Kattegat are scattered along the Jutland and Swedish coast and include the Limfjorden, Gudenå, Rönne ^̊, Lagan,
Nissan, Ätran and Viskan rivers as well as Göta River, which occasionally spills into the Kattegat under northerly wind conditions. The KattegatSkagerrak front in the northern part, where surface salinities can rapidly change by 5 to $10 \mathrm{psu}$ (Jakobsen 1997), is an important feature leading to locally increased primary production (Richardson 1985). During periods of westerly winds, which dominate in the region, upwelling may take place along the Jutland coast (Kiørboe 1996).

\section{MATERIALS AND METHODS}

Within the framework of DNAMAP (http:// mads.dmu.dk), data on temperature, primary production as well as phytoplankton and zooplankton biomass were collected at 13 stations (albeit to varying degrees) in the Kattegat (see Fig. 1) during the period 1989 to 1997 . Stations with water depths $<20 \mathrm{~m}$ were defined as coastal (8 stations), the others as open-water ( 5 stations). Monitoring was conducted by Danish counties in co-operation with the National Environmental Research Institute of Denmark. In 1998 monitoring of primary production and phytoplankton/zooplankton biomass was reduced to only 2 of the former sampling sites (Stns 409 and 925). Sampling intensities for the primary production and phytoplankton biomass data at the various stations for the period 1989 to 1997 are listed in Table 1. Some stations had data for a limited number of years only, and there were large variations in the yearly sampling frequency amongst stations. The data set comprised 1079 observations of primary production, 901 observations of phytoplankton biomass, 140 observations of zooplankton biomass, and 1858 observations of temperature.

Primary production was measured using standard ${ }^{14} \mathrm{C}$ techniques for surface (<10 m depth) water samples incubated in the dark at various irradiance levels (Steemann Nielsen 1952). The uptake of ${ }^{14} \mathrm{C}$ was measured (after $2 \mathrm{~h}$ ) and the corresponding photosynthesis-irradiance $(P-I)$ curve constructed in each case. $P_{\max }$ was found as the maximum production rate from each $P$ - $I$ curve. Potential daily primary production levels were calculated down to $10 \mathrm{~m}$ using standard insolation rates and measured light attenuation coefficients. Production levels were scaled by chl a measured at various depths and subsequently integrated over depth to produce estimates of primary production in the upper mixed layer (0 to $10 \mathrm{~m}$ depth layer). Phytoplankton and microzooplankton were collected from an integrated water sample (combination of 2 to 5 discrete water samples from 0 to $10 \mathrm{~m}$ ); the species were iden- 
tified; the plasma volume was estimated from the dimensions of individuals using a set of geometric shapes (diatoms: Strathman 1967, other species: HELCOM 2001); and the carbon biomass was calculated using fixed volume-to-carbon relationships for the various

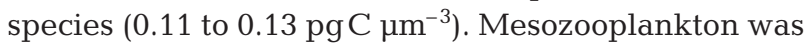
sampled with a $100 \mu \mathrm{m}$ mesh net or a submersed pump fitted with a $100 \mu \mathrm{m}$ net towed through the water column from $25 \mathrm{~m}$ depth to the surface at a velocity of ca. $0.5 \mathrm{~m} \mathrm{~s}^{-1}$. Mesozooplankton species were identified, and the lengths of individual specimens were measured and converted to carbon biomass using empirical length-to-weight relationships for the various species. Zooplankton biomass was calculated as the sum of microzooplankton and mesozooplankton biomasses.

\section{SPACE-TIME DATA INTERPOLATION}

For the 13 DNAMAP stations during the period 1989 to 1997 , the data for primary production, phytoplankton biomass and temperature were irregular in both time and space (Table 1). The so-called gaps in time were filled by means of a general linear model (McCullagh \& Nelder 1989) which describes variations between stations with a weekly resolution. The underlying assumption of the model was that temporal variations showed similar trends at all stations, differing only by a scaling factor $\left(\right.$ station $\left._{i}\right)$. The model was estimated for primary production, phytoplankton biomass, $P_{\max }$ and temperature separately (denoted by $Y_{i j}$ ).

$$
\begin{gathered}
Y_{i j}=\underset{\mathbb{I}}{\operatorname{station}_{i} \cdot \text { week }_{j} \cdot \varepsilon_{i j}} \\
X_{i j}=\log \left(Y_{i j}\right)=\log \left(\operatorname{station}_{i}\right)+\log \left(\text { week }_{j}\right)+e_{i j} \\
\text { and } e_{i j}=\log \left(\varepsilon_{i j}\right) \in N\left(0, \sigma^{2}\right)
\end{gathered}
$$

Table 1. Sampling intensities of primary production (first value) and phytoplankton biomass (second value) at the various stations for the period 1989 to 1997. Empty cells and - signify data not collected

\begin{tabular}{|lccccccccc|}
\hline Stn & 1989 & 1990 & 1991 & 1992 & 1993 & 1994 & 1995 & 1996 & 1997 \\
\hline 1001 & $6 / 6$ & $7 / 7$ & $8 / 7$ & $7 / 7$ & $9 /-$ & $7 / 8$ & $4 / 6$ & $1 / 5$ & $3 /-$ \\
190004 & $9 / 12$ & $13 / 10$ & $20 / 21$ & $22 / 22$ & $22 / 22$ & $21 /-$ & $22 / 21$ & $20 / 19$ & $23 / 24$ \\
$1937^{a}$ & & $11 /-$ & $12 /-$ & $11 /-$ & & & & & \\
1939 & & $12 / 9$ & $11 / 10$ & $11 /-$ & $11 / 12$ & $9 / 10$ & $10 / 12$ & $9 / 11$ & $10 /-$ \\
1993 & & & & & $32 /$ & $23 / 25$ & $28 / 31$ & $27 / 29$ & $26 /-$ \\
20004 & $1 / 7$ & $1 / 13$ & $-/ 12$ & $-/ 13$ & & $-/ 12$ & & $12 / 12$ & $13 / 12$ \\
3310 & $11 /-$ & $12 / 14$ & $9 / 12$ & $23 / 25$ & $19 / 21$ & $16 / 20$ & $16 / 20$ & $19 / 21$ & $18 / 21$ \\
$403^{a}$ & $3 /-$ & $4 /-$ & $4 /-$ & $6 /-$ & $5 /-$ & $6 /-$ & $5 /-$ & $5 /-$ & $1 /-$ \\
409 & $8 / 6$ & $9 / 7$ & $9 / 7$ & $5 / 7$ & $8 / 8$ & $8 / 6$ & $8 / 7$ & $6 / 6$ & $5 / 7$ \\
413 & $8 / 6$ & $6 / 7$ & $9 / 7$ & $7 / 7$ & $8 / 8$ & $8 / 6$ & $8 / 7$ & $6 / 5$ & $5 / 7$ \\
4410 & $11 /-$ & $11 / 13$ & $10 / 12$ & $20 / 22$ & $21 / 22$ & $18 / 22$ & $15 / 21$ & $20 / 23$ & $17 /-$ \\
$921^{a}$ & $6 /-$ & $7 /-$ & $8 /-$ & $4 /-$ & $8 /-$ & $7 /-$ & $6 /-$ & $4 /-$ & $3 /-$ \\
925 & $7 / 6$ & $8 / 7$ & $7 / 7$ & $7 / 7$ & $10 / 8$ & $9 / 7$ & $7 / 7$ & $5 / 6$ & $6 / 6$ \\
a Phytoplankton biomass was not measured at these stations. Biomass data \\
from nearest station was used in budget model \\
\hline \multicolumn{10}{|c}{}
\end{tabular}

where $Y_{i j}$ is the observation, $X_{i j}$ is the log-transform of $Y_{i j}$ station $_{i}$ is the station level ( $i=$ station identification), week $_{j}$ is the weekly resolution over the $9 \mathrm{yr}$ period $(j=$ $1, \ldots . .469)$ and $e_{i j}$ is the residual assumed to be normally distributed. All variables except temperature were logtransformed to obtain an additive model before the general linear model was applied. Predictions from log-transformed variables were back-transformed:

$$
\hat{Y}_{i j}=\exp \left(E\left[X_{i j}\right]+\frac{V\left[X_{i j}\right]}{2}\right)
$$

where $E\left[X_{i j}\right]$ is the predicted value and $V\left[X_{i j}\right]$ is the variance of the prediction for the log-transformed variable. Missing data only were replaced by predictions from Eq. (1), i.e. observed data were not replaced by predictions. Estimates of week $_{j}$ in Eq. (1) could not be obtained for weeks without samples, and predictions for these gaps were subsequently filled by linear interpolation in time. Finally, 3 out of the 13 stations did not have measurements of phytoplankton biomass at all, and, for the budget model (see below), data from the nearest neighbouring station were used. Hence, time series with equidistant observations of phytoplankton biomass, primary production, $P_{\max }$ and temperature were constructed by estimating gaps in the time series by means of Eq. (1), linear interpolation and data from the nearest neighbouring station. Observed data accounted for 14 to $25 \%$ of the complete data set for the 4 variables, with phytoplankton biomass and temperature having the lowest and highest proportions of observed data, respectively.

The space-time interpolation approach is exemplified in Fig. 2, which shows modelled time series of primary production for the stations with the most (Stn 190004) and the least (Stn 20004) data. Thus, primary production was predicted for 1991 to 1995 at Stn 20004, a site where there were no measurements for this period. The prediction values were based solely on the trends documented at other stations in the Kattegat. The general linear model Eq. (1) gave a good description of the observed data: $\mathrm{R}^{2}=0.80$ for log-transformed primary production, $\mathrm{R}^{2}=0.76$ for logtransformed phytoplankton biomass, $\mathrm{R}^{2}=0.68$ for log-transformed $P_{\text {max }}$ and $\mathrm{R}^{2}=0.98$ for temperature. Correlations between stations calculated by means of data observed in identical weeks were high (all correlations significant in the range $r=0.49$ to 1.00 for temperature; $67 \%$ significant in the range $\mathrm{r}=$ 0.39 to 0.98 for log-transformed primary production; $43 \%$ significant in the range $\mathrm{r}=0.29$ to 0.95 for $\log$-transformed $P_{\max }$ 

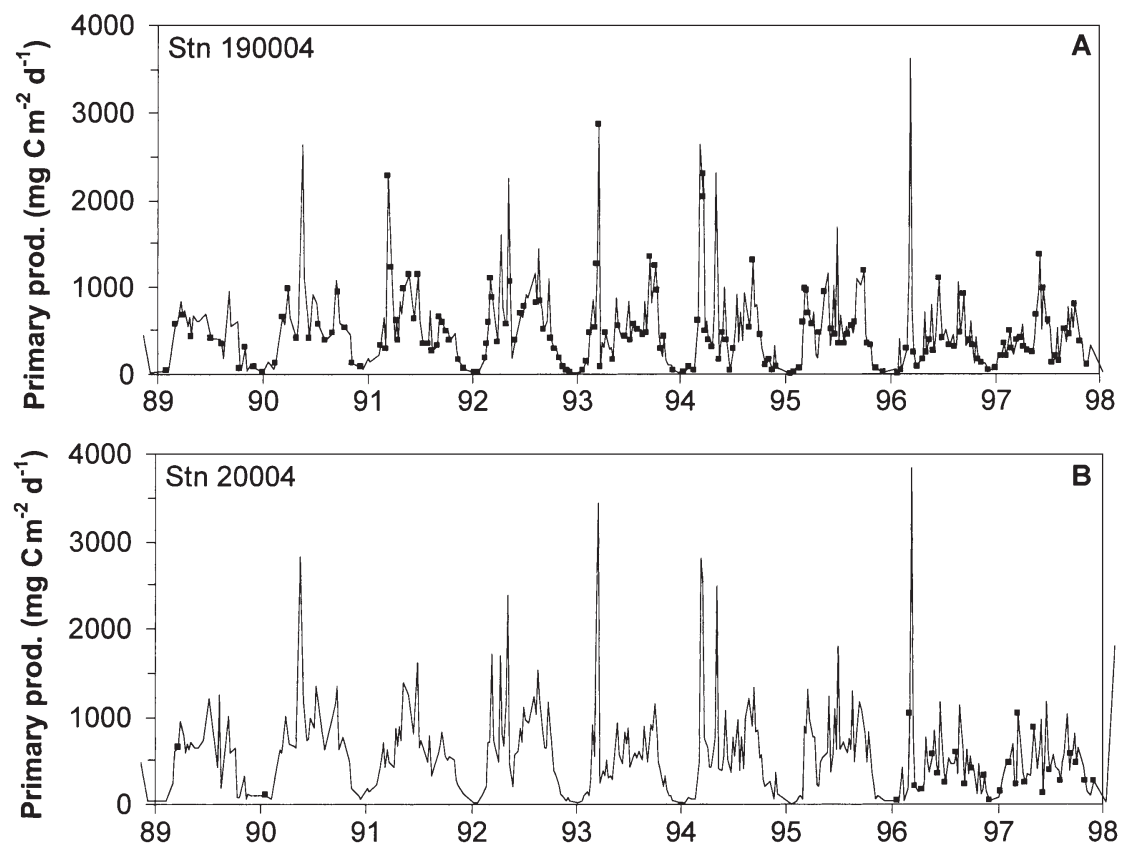

Fig. 2. Space-time interpolation of primary production (1989 to 1997) for (A) Stn 190004 and (B) Stn 20004. Observed data are indicated by squares, and modelled data (weekly resolution) are indicated by lines
The results of the zooplankton biomass model averaged over the 4 stations are shown in Fig. 3. Seasonal variations were essentially unimodal, with maximum values in the beginning of July each year. Annual levels varied by up to a factor of 2, with 1995 having the highest and 1997 having the lowest biomass values. Stn 1001 had the lowest mean biomass

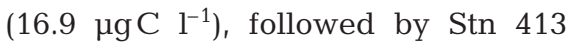
$\left(23.8 \mu \mathrm{g} \mathrm{C}^{-1}\right.$ ). Stns 409 and 925 had the highest mean biomass values (29.7 and $27.7 \mu \mathrm{gC}^{-1}$, respectively). Nevertheless, 3 of the 4 stations (Stns 1001, 413 and 925) were open-water sites and therefore presumably not representative of the coastal zone. Variations between stations were less than 2-fold, and the 2 stations with the highest mean zooplankton biomass (Stns 409 and 925) were situated nearer the coast than the other 2 stations. The relatively simple nature of the model for zooplankton (Eqs. 3 \& 4)
$47 \%$ significant in the range $r=0.37$ to 1.00 for logtransformed phytoplankton biomass; $\mathrm{p}<0.05$, $t$-test), justifying the underlying assumption of similar trends in Eq. (1). Non-significant correlations were mostly based on a low number of observations.

Mesozooplankton data were too scarce to allow for space-time interpolation using Eq. (1). Samples were available from 4 stations only (Stns 1001, 409, 413 and 925; see Fig. 1) and sampling frequency ranged from 1 to 22 samples $\mathrm{yr}^{-1}$, these being unevenly distributed amongst stations. Zooplankton biomass was modelled assuming that station effect as well as inter-annual and seasonal variations were multiplicative factors. Thus,

$$
\begin{aligned}
& Y_{i j}=\operatorname{station}_{i} \cdot \underset{\Uparrow}{\text { year }_{j}} \cdot \operatorname{season}_{k} \cdot \varepsilon_{i j k} \\
& X_{i j k}=\log \left(Y_{i j k}\right)=\log \left(\text { station }_{i}\right)+\log \left(\text { year }_{j}\right) \\
& +\log \left(\operatorname{season}_{k}\right)+e_{i j k} \\
& \text { and } e_{i j k}=\log \left(\varepsilon_{i j k}\right) \in N\left(0, \sigma^{2}\right)
\end{aligned}
$$

where station $_{i}$ is the station level ( $i=$ station identification), and year $j$ is the inter-annual variation ( $j=1989$ to 1997). The seasonal variation $\left(\right.$ season $_{k}$ ) was modelled as a continuous function over the entire year by a second-order harmonic model with a mean value of 1 :

$$
\operatorname{season}_{k}=1+\sum_{l=1}^{2} a_{l} \cdot \cos \left(\frac{1 \cdot 2 \pi \cdot k}{365}\right)+b_{l} \cdot \sin \left(\frac{l \cdot 2 \pi \cdot k}{365}\right)
$$

where $k$ denotes the Julian day of the sample, and $a_{1}$ and $b_{l}$ are parameters estimated from data. and the less systematic variation in the observed data are associated with a poorer fit $\left(\mathrm{R}^{2}=0.50\right.$ for logtransformed zooplankton data).

\section{PHYTOPLANKTON BUDGET MODEL APPROACH}

The budget model was based on the assumption that net primary production depended on 2 sources of nitrogen: (1) regenerated production, based on a recycling of nutrients in the upper mixed layer and (2) new production, based on an external supply of nutrients to the upper mixed layer. The latter included the accumulation of nutrients during the winter period. It was assumed that phytoplankton biomass was lost from the upper mixed layer by 2 mechanisms: (1) sedimentation and (2) predation and decay. The loss of phytoplankton biomass was calculated as the difference between net primary production (net PP) and the change in phytoplankton biomass ( $\Delta$ biomass). Predation and decay processes included all loss processes for which the phytoplankton constituents remained in the upper mixed layer. Finally, it was assumed that the flux of phytoplankton biomass from predation and decay was used for either (1) growth of grazers or (2) regenerated production. The conceptual model is schematised in Fig. 4. The model contains 6 processes which were not monitored but calculated in sequence: net primary production, sedimentation, predation and decay, loss to higher trophic levels, regenerated production, and 


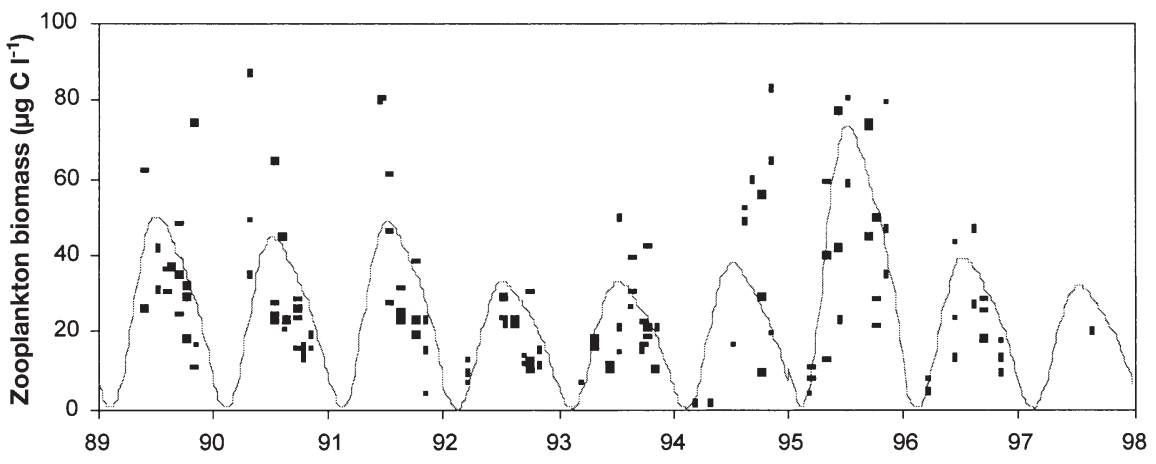

Fig. 3. Temporal variation in zooplankton biomass for 1989 to 1997 . There are 140 observed data sets from 4 stations, and only 2 observations show values above $100 \mu \mathrm{gC} \mathrm{l}^{-1}$. Values predicted by the model described in the text (solid line) are averages for the 4 stations

new production. The model addresses processes in the upper mixed layer only, defined as the 0 to $10 \mathrm{~m}$ depth layer.

Net primary production was calculated from observed primary production by subtracting respiration which was modelled as:

Respiration $=$ light respiration + dark respiration

$$
=L \cdot R_{\mathrm{L}} \cdot P_{\max }+(24-L) \cdot R_{\mathrm{D}} \cdot P_{\max }
$$

where $L$ is the daylength in hours, and $R_{\mathrm{L}}$ and $R_{\mathrm{D}}$ are the fractions of $P_{\text {max }}$ used for light and dark respiration, respectively. Moreover, the light respiration rate was assumed to be twice the dark respiration rate (Langdon 1993). Maintenance respiration, as described in Langdon (1993), was not considered. It is generally believed that respiration is in the order of 5 to $10 \%$ of the light-saturated gross photosynthetic rate (Cole et al. 1991, Langdon 1993). However, primary production measured by the ${ }^{14} \mathrm{C}$ technique can vary anywhere between gross and net primary production, depending on length of incubation and phytoplankton growth rate (Peterson 1978, Dring \& Jewson 1982). In winter the phytoplankton biomass remained at an almost constant low level, and we assumed that respiration accounted for half of the measured primary production and that the other half was attributed to the loss processes described by the model (Fig. 4). Hence, the fractions of $P_{\max }$ used for respiration $\left(R_{\mathrm{L}}\right.$ and $\left.R_{\mathrm{D}}\right)$ were determined so that respiration would account for approximately $50 \%$ of the ${ }^{14} \mathrm{C}$ measurements during the darkest period of the year (Arístegui et al. 1996), resulting in $R_{\mathrm{L}}=3 \%$ and $R_{\mathrm{D}}=1.5 \%$.

The loss of phytoplankton biomass was attributed to processes for which phytoplankton biomass remained in the upper mixed layer (predation and decay process) and those for which phytoplankton biomass was transported out of this layer (sedimentation). Thus, the model is a coarse but operational simplification of the com- plex mosaic of processes describing the pelagic food web. Predation and decay processes would include zooplankton grazing, lysis by bacteria and viruses, exudation of organic material from cells, etc. Sedimentation would include sinking, entrainment and diffusion of phytoplanktonic material across the pycnocline. It was assumed that the predation and decay processes were governed mainly by zooplankton grazing. Predation and decay processes were described by adopting the potential grazing model of Huntley \& Lopez (1992) using an average growth yield of $33 \%$ (Hansen et al. 1997):

$\underset{\text { grazing }}{\text { Potential }}=k_{\text {grazing }} \cdot 0.135 \cdot$ zoobiomass $\cdot \exp ^{0.111 \cdot \text { temperature }}$

where zoobiomass is the zooplankton biomass (Fig. 3) and $k_{\text {grazing }}$ is a parameter linking zooplankton grazing with phytoplankton losses, which would be equal to one if the grazing equation of Huntley \& Lopez (1992) was satisfied. Although Eq. (6) is based on experimental studies of copepods without food limitation, and the zooplankton biomass used as input included both micro- and mesozooplankton, it was assumed that the shape of the potential grazing rate would adequately describe any seasonal variations in predation and decay. Furthermore, net primary production and potential grazing rate were assumed to be in equilibrium (potential grazing = actual grazing) during the summer period (May to August), and the parameter $k_{\text {grazing }}$ was determined by fitting Eq. (6) to phytoplankton losses calculated as net PP - $\Delta$ biomass for this period only. This summer grazing model was subsequently extended to the rest of the year, during which variations in potential grazing were attributed to changes in temperature and zooplankton biomass only. Thus, $k_{\text {grazing }}$ is a scaling parameter presumably larger than 1 because grazing calculated by means of the Huntley \& Lopez (1992) model cannot entirely account for all predation and

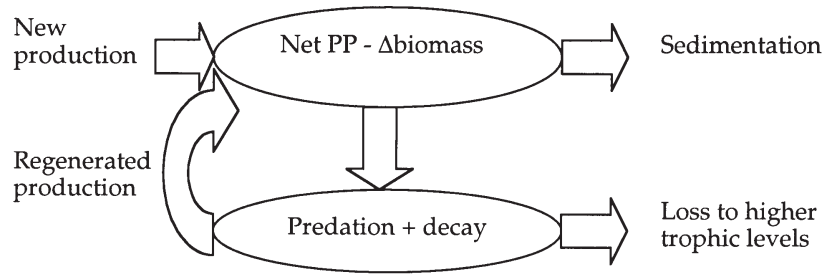

Fig. 4. Flow diagram of fluxes in budget model. Conversion between phytoplankton constituents was calculated using Redfield ratios 
decay processes. It is, however, assumed that the proportion of predation and decay processes attributed to zooplankton grazing is constant over the year.

In cases where the phytoplankton loss rate exceeded the grazing rate, autochthonous material would sediment out of the upper mixed layer. Sedimentation was consequently modelled as:

\section{Sedimentation $=$ $\max ($ net $P P-\Delta$ biomass - potential grazing, 0 )}

The assumptions of this model were that episodic spring, summer and autumn blooms would give rise to sedimentation of phytoplankton biomass (Nielsen \& Kiørboe 1991), whereas periods without blooms would be characterised by steady-state conditions under which production would equal losses within the euphotic zone. This underlying assumption corresponds to the findings of Olesen \& Lundsgaard (1995), who reported that sedimentation of phytoplankton carbon was dominated by the spring and autumn blooms in the Kattegat. The composite budget model (Fig. 4) did not include the sedimentation of faecal pellets from copepods, which in previous studies was found to be of minor importance in this context (Lundsgaard \& Olesen 1997).

The constituent fluxes of predation and decay processes are those diverting material towards higher trophic levels (build-up of grazer biomass) and those involving recycled material (regenerated production). It was assumed that a constant fraction $(\alpha)$ of grazing was used for higher trophic levels, the remaining fraction $(1-\alpha)$ being channelled into regenerated production. Hansen et al. (1997) found that growth yields varied between 0.10 and 0.45 for different grazers, with a mean of 0.33 , which we applied for our model $(\alpha=0.33)$. The difference between net primary production and regenerated production corresponds to new production.

The phytoplankton budget model was applied to the time series data for primary production, phytoplankton biomass, $P_{\max }$ zooplankton biomass and temperature, the output being estimated fluxes of $\mathrm{C}, \mathrm{N}$ and P ( illustrated in Fig. 4). These weekly fluxes were combined into yearly values for each of the 13 stations and subsequently integrated over the entire Kattegat for each year from 1989 to 1997, using ordinary kriging with a robust linear variogram model without a nugget effect (Cressie 1993). The spatial resolution of the kriging interpolation was $1 \times 1 \mathrm{~km}$. It was important to use a spatial interpolation method instead of averaging over stations because most stations were located in the coastal zone ( 8 out of 13), which have biased mean values (see below).

Nitrogen and phosphorus fluxes were calculated from the annual phytoplankton carbon fluxes using Redfield molar ratios for phytoplankton composition, i.e. $C: N: P=106: 16: 1$ (Redfield 1958). In the upper mixed layer new phytoplankton production is sustained by nutrients supplied to the Kattegat from the land and atmosphere, together with advection from adjoining seas and upward mixing of nutrients. The upward mixing of nutrients was estimated from a hydrodynamical model (Gustafsson 2000) by means of monthly and depth-dependent salinity-nutrient relationships (B. Gustafsson unpubl. data). Furthermore, the nutrient requirements for new production predicted by the model were compared with inputs from the land and atmosphere and from estimated upward mixing.

\section{RESULTS}

From the results of the phytoplankton budget model, we choose to focus on pooled data sets for up to 13 stations as well as 2 individual stations, these being Stn 190004, which is one of the most eutrophic (see below) and intensively sampled station (Table 1), and Stn 413 , which is less eutrophic (see below). Weekly rates from the model and seasonal rates are expressed in units of days, whereas rates averaged over single years or the entire period are expressed in units of years. The term bloom usually relates to relatively high phytoplankton biomass levels. In the present study we use it to denote strong, rapid increases in primary production.

\section{Station-specific trends}

Primary production rates were high from March to October (663 $\mathrm{mgC} \mathrm{m}^{-2} \mathrm{~d}^{-1}$ ) at Stn 190004 (Fig. 5A), with major blooms occurring in spring (March to May) and minor blooms during summer and fall. Similar trends (seasonal average of $376 \mathrm{mgC} \mathrm{m}^{-2} \mathrm{~d}^{-1}$ ) were observed at Stn 413 (Fig. 5E), although the timing and magnitude of blooms differed. The productive period from March to October accounted for $91 \%$ of annual production rates at both stations. Substantial differences were found in the primary production rates between stations (Table 2). During the 9 yr study period, the highest level was observed at the 3 stations located off the North Zealand coast (Stns 1937, 1993 and 20004), which had an average primary production of $196 \mathrm{~g} \mathrm{C} \mathrm{m}^{-2} \mathrm{yr}^{-1}$. Off the Jutland coast primary production was on average $170 \mathrm{~g} \mathrm{C} \mathrm{m}^{-2} \mathrm{yr}^{-1}$ at the 3 stations with the highest rates (Stns 190004, 3310 and 4410). The high primary production at Stns 1937, 1993 and 20004 was not associated with higher levels of phytoplankton biomass (9 yr averages: 43 and $82 \mu \mathrm{gC}$ $\mathrm{I}^{-1}$ for the 3 stations along the North Zealand coast and Jutland coast, respectively). For the 8 coastal stations and the 5 open-water stations, average values were 171 and $105 \mathrm{~g} \mathrm{C} \mathrm{m}^{-2} \mathrm{yr}^{-1}$, respectively (Table 2). Thus, 


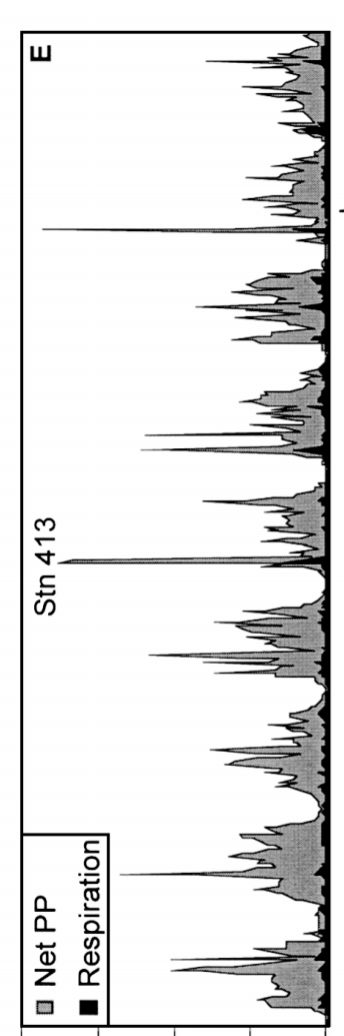

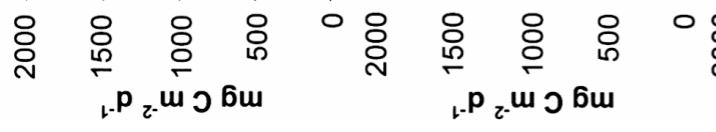
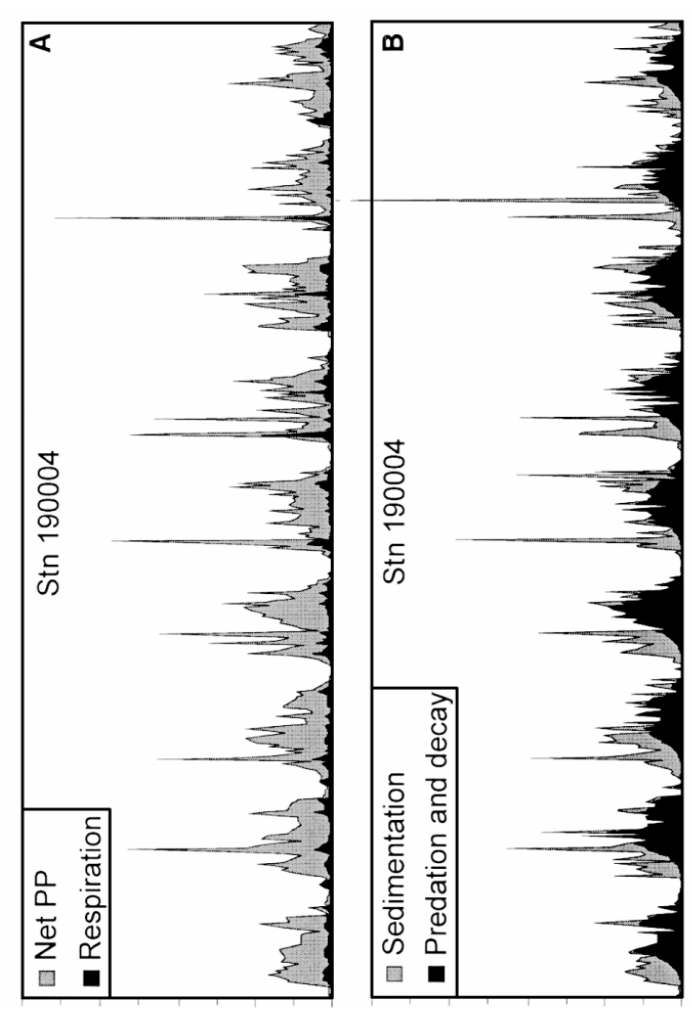

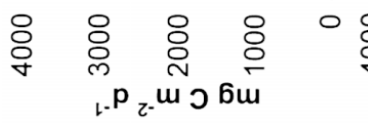

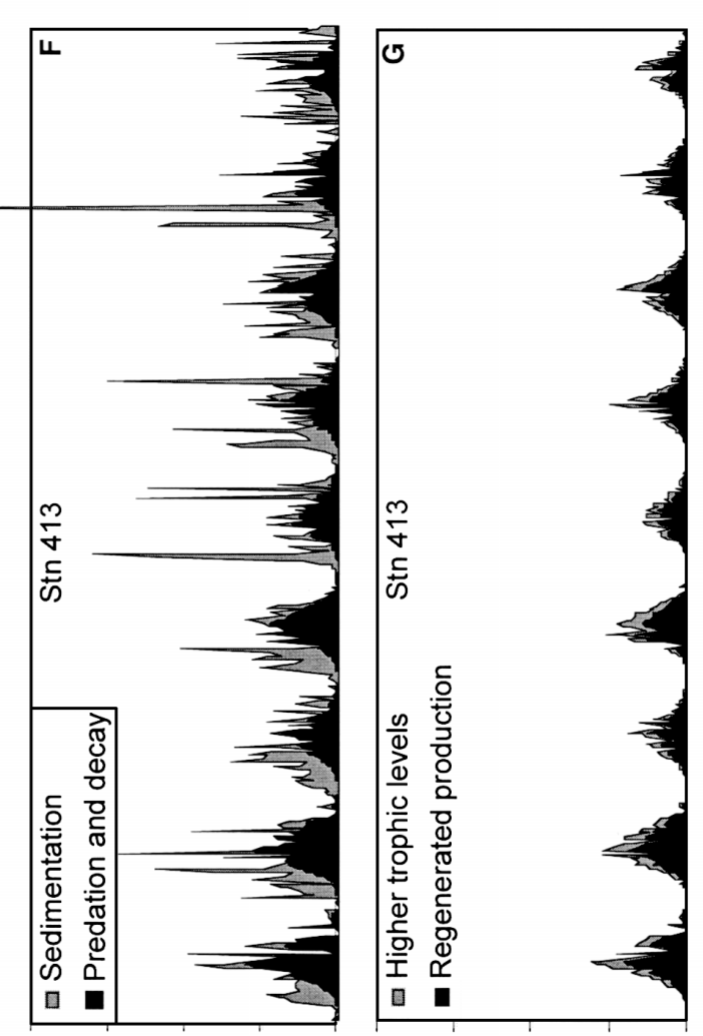

各 \&

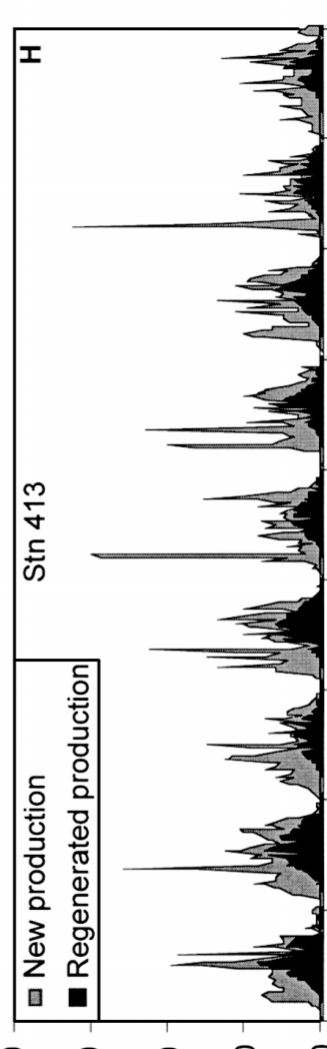

$\infty$

ล

तथ

\&

牙承

น

क

웅

मे

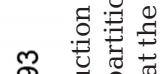

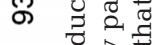

a

กิ :

范

5 四券

$<0$

4

요웜

ه $\vec{\circ} \dot{\vec{\theta}}$

总卷 :

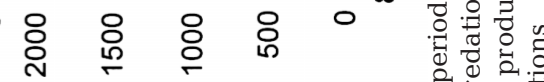

क्ते
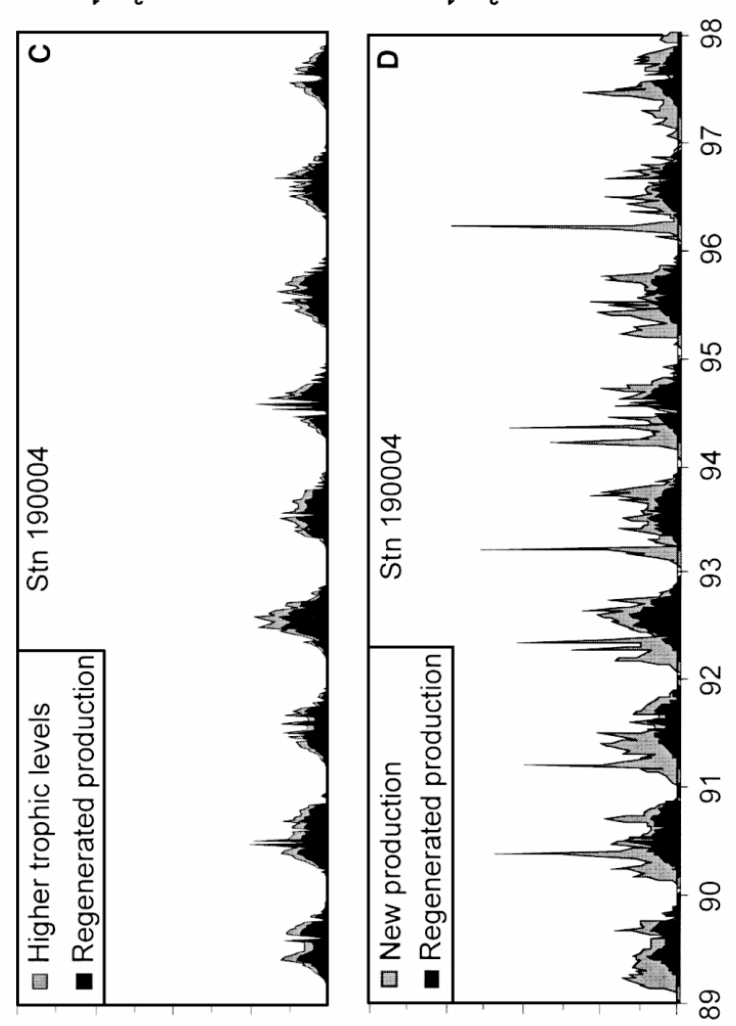

.

近

ช :

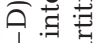

48

눙. 응

实诺

in

荧

w

을

总离

वै 증

年

점

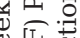

3 ต

०

过

क :

品

is

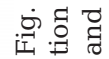


Table 2. Average process rates for the 13 stations over the entire $9 \mathrm{yr}$ study period. All process rates are in $\mathrm{gC} \mathrm{m}^{-2} \mathrm{yr}^{-1}$

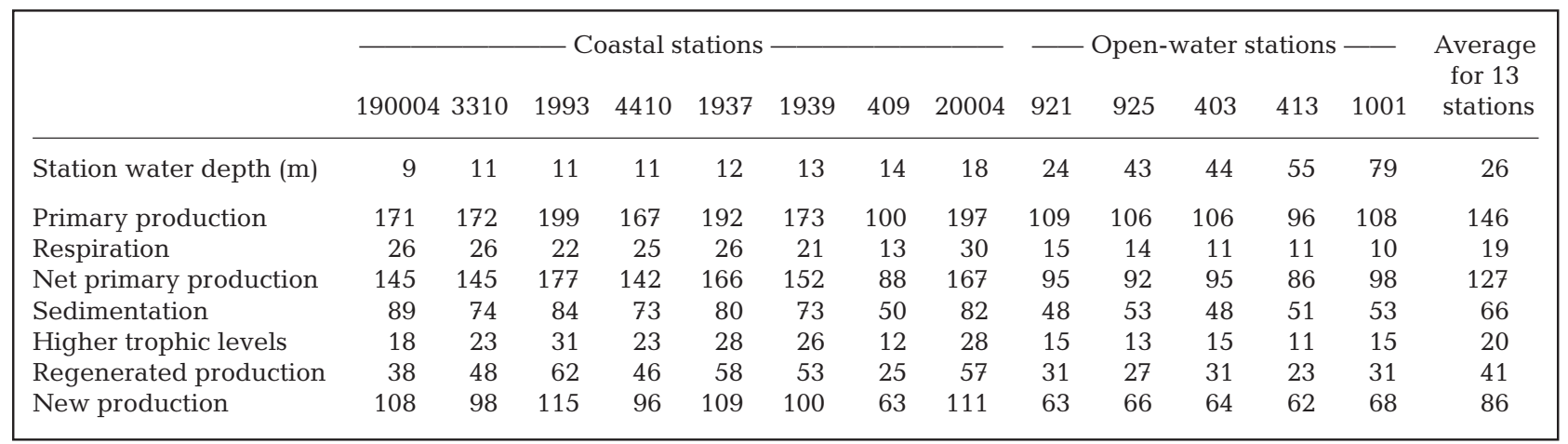

primary production in the coastal zone was almost twice that recorded at the open-water stations.

Phytoplankton respiration showed little seasonal variation at both Stn 190004 (Fig. 5A) and Stn 413 (Fig. 5E). By contrast, net primary production was high from March to October, with highest values in spring (Fig. 5A,E). Seasonal variation patterns (determined as monthly average values over the entire period) showed values ranging from 33 to $155 \mathrm{mg} \mathrm{C} \mathrm{m}^{-2} \mathrm{~d}^{-1}$ for respiration and from 31 to $741 \mathrm{mgC} \mathrm{m} \mathrm{m}^{-1}$ for net primary production at Stn 190004 . Monthly average values at Stn 413 ranged from 20 to $61 \mathrm{mg} \mathrm{C} \mathrm{m}^{-2} \mathrm{~d}^{-1}$ for respiration and from 25 to $416 \mathrm{mgC} \mathrm{m}^{-2} \mathrm{~d}^{-1}$ for net primary production. The ranges in values for average respiration and net primary production over the $9 \mathrm{yr}$ period for all stations combined were 10 to $30 \mathrm{~g} \mathrm{C} \mathrm{m}^{-2} \mathrm{yr}^{-1}$ and 86 to $177 \mathrm{~g} \mathrm{C} \mathrm{m}^{-2} \mathrm{yr}^{-1}$, respectively, with coastal stations having the highest values. Combining all weekly data sets seasonally for all stations over the entire study period, it was found that respiration accounted for approximately 7 and $50 \%$ of primary production in summer (May to August) and winter (December to January), respectively (data not shown). Over the period 1989 to 1997, the proportion of primary production used for respiration varied from 9 to $15 \%$ between stations, the coastal shallow-water stations having the

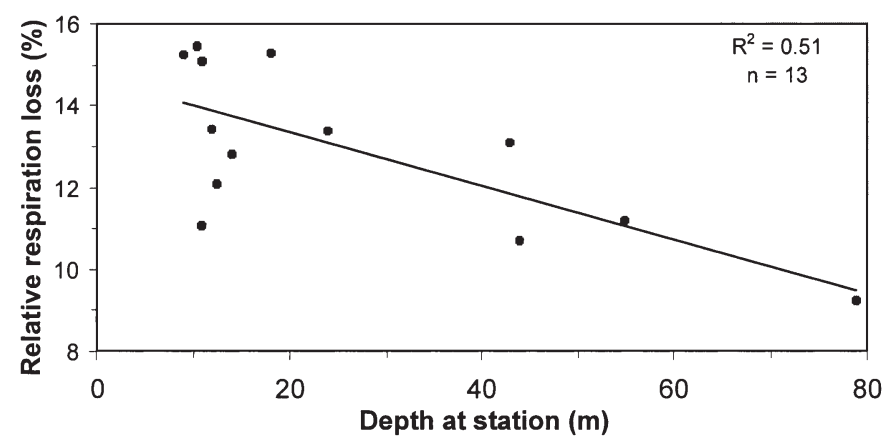

Fig. 6. Linear regression between the proportion of primary production used for respiration in the upper mixed layer (averaged over 1989 to 1997 for the 13 stations) and water depth $(\mathrm{p}=0.0057, F$-test $)$ highest values (Fig. 6). Thus, relative respiration loss was significantly related to station water depth $(\mathrm{p}<$ 0.01, F-test).

Predation and decay rates were high from May to September (356 and $229 \mathrm{mg} \mathrm{C} \mathrm{m}^{-2} \mathrm{~d}^{-1}$ for Stns 190004 and 413, respectively). This period alone accounted for 82 to $84 \%$ of the annual rates at the 13 stations. Consequently, losses to higher trophic levels and regenerated production also showed summer maxima (Figs. 5C,G, \& 7). The importance of zooplankton grazing also differed between the coastal and open-water stations. Estimates of $k_{\text {grazing }}$ by means of Eq. (6) were in the range of 1 to 1.25 for the 5 open-water stations and around 2 for the 8 coastal stations.

Sedimentation occurred mainly during the spring blooms and also during occasional minor blooms in summer and autumn (Fig. 5B,F). The major spring blooms generally occurred in March (Fig. 5A,E). Over the 9 yr period this single month accounted for 25 and $24 \%$ of annual sedimentation at Stns 190004 and 413, respectively. Some years (e.g. 1992 and 1994) were characterised by several major blooms from March to May (Fig. 5A,E). In all years at both stations, all major peaks in primary production were in the period March to May, except for 1997, when the first major bloom occurred in June. If we consider March to May as the spring period and September to October as the autumn period, sedimentation during these periods accounted for 55 to 65 and 11 to $18 \%$, respectively, of annual sedimentation over the entire period at the 13 stations.

At Stns 190004 and 413, strong seasonal variations in fluxes resulting from loss of phytoplankton biomass were recorded (Fig. 7). March to May had the highest sedimentation, followed by September and October at both stations. By contrast, loss to higher trophic levels and regenerated production were closely linked to variations in zooplankton biomass (Fig. 3), with high values from May through September. Ranges in average values for the 13 stations over the $9 \mathrm{yr}$ period were 48 to $89 \mathrm{~g} \mathrm{C} \mathrm{m}^{-2} \mathrm{yr}^{-1}$ for sedimentation, 11 to $31 \mathrm{~g} \mathrm{C} \mathrm{m}^{-2}$ $\mathrm{yr}^{-1}$ for loss to higher trophic levels, and 23 to $62 \mathrm{gC}$ 
$\mathrm{m}^{-2} \mathrm{yr}^{-1}$ for regenerated production. For all 3 flux types, process rates were higher at coastal stations and lower at open-water stations (Table 2).

Net primary production was based largely on new production in the late winter to early spring (January to April), and on a combination of both new and regenerated production from late spring, throughout summer and into early winter each year in the period 1989 to 1997 (Figs. 5D,H \& 8). Regenerated production varied between 62 and $115 \mathrm{~g} \mathrm{C} \mathrm{m}^{-2} \mathrm{yr}^{-1}$ at the 13 stations, and the proportions of net primary production constituted by regenerated production were 27 to $33 \%$ for openwater stations and 26 to $35 \%$ for the coastal stations (Table 2).

\section{Regional trends}

Spatially integrated carbon fluxes from the budget model for the Kattegat as a whole were positively correlated to annual primary production levels (Table 3), i.e. years with higher primary production were associated with higher rates of respiration $(r=0.52, \mathrm{p}=0.15$,

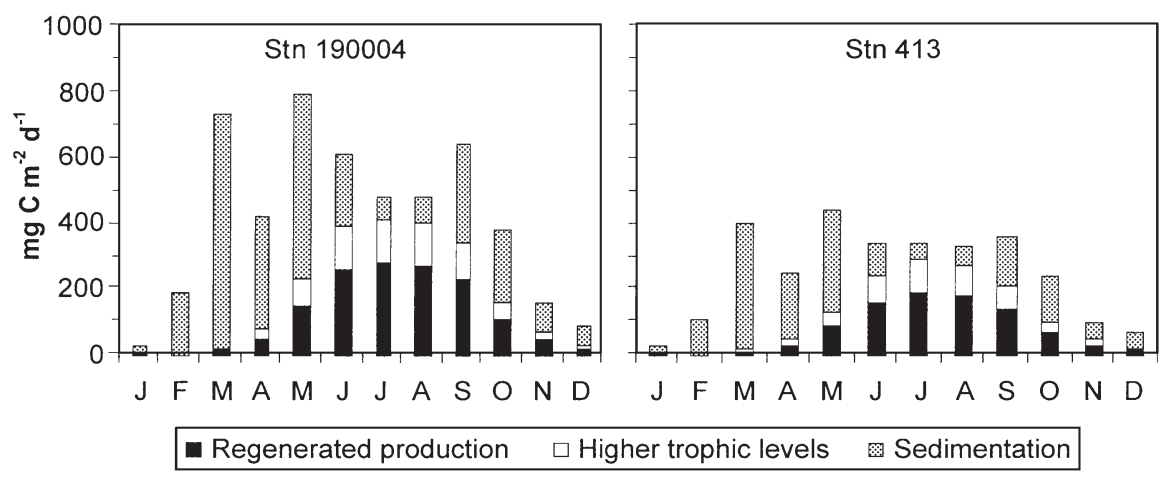

Fig. 7. Monthly variations in net primary production, partitioned into regenerated production, loss to higher trophic levels, and sedimentation (average values over 1989 to 1997)
Stn 190004

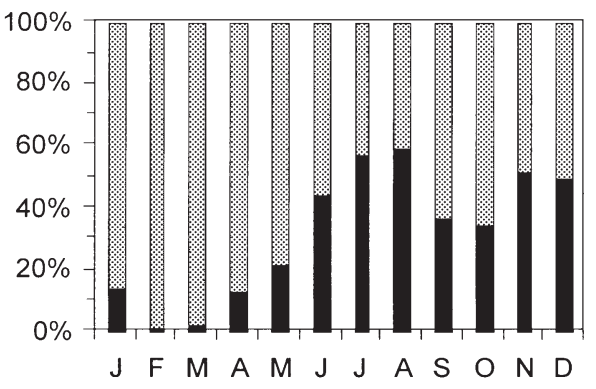

Stn 413

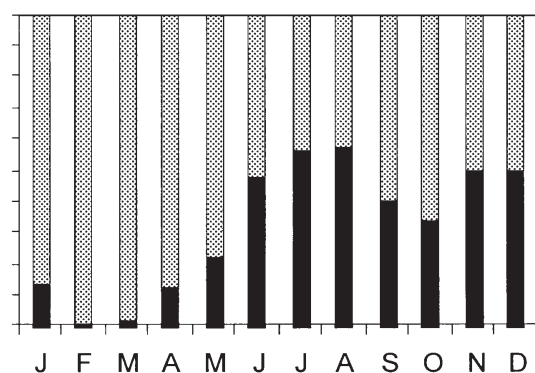

J F M A M J J A S O N D
Regenerated production $\quad$ New production

Fig. 8. Monthly variations in the relative proportions of new and regenerated production, which together make up net primary production (average values over 1987 to 1997 ) $t$-test), net primary production $(\mathrm{r}=0.99, \mathrm{p}<0.001$, $t$-test), sedimentation ( $\mathrm{r}=0.68, \mathrm{p}<0.05, t$-test), loss to higher trophic levels ( $\mathrm{r}=0.82, \mathrm{p}<0.01, t$-test) and regenerated production $(\mathrm{r}=0.82, \mathrm{p}<0.01, t$-test $)$. Interannual variations of the flux estimates (Table 3 ) were ca $15 \%$ for all processes except loss to higher trophic levels and regenerated production, for which the values were ca $30 \%$. Comparing these regional estimates, which takes the spatial distribution of stations into account, with the average levels for the 13 stations for years combined (Table 2) showed that the latter were approximately $25 \%$ higher.

For the Kattegat as a whole over the entire study period, average values of sedimentation and regenerated production accounted for 54 and $31 \%$, respectively, of annual net primary production (Table 3 ). The amount of net primary production which was incorporated into higher trophic levels was relatively low $(15 \%)$, the interannual variation ranging between 11 and $19 \%$. Years with the most pronounced spring blooms and highest sedimentation rates (e.g. 1993 and 1996) had low proportions of net primary production incorporated into higher trophic levels.

For the region as a whole during the 9 yr study period, net primary production was primarily based on new production (average $70 \%$ ) and secondarily on regenerated production (average $30 \%$ ) (Table 3). Estimates of new production, converted into $\mathrm{N}$ and $\mathrm{P}$ units by means of Redfield ratios, were compared to the external supply of nutrients from land and atmosphere (Hansen et al. 2000), and to internal entrainment fluxes calculated from a hydrodynamical model (B. Gustafsson unpubl. data; Table 4). The hydrodynamical model included regional entrainment of nutrients by wind mixing and advection, but it did not consider upwelling or diffusion processes (Gustafsson 2000). Such internal nutrient sources have therefore been underestimated. The land and atmospheric contribution of nitrogen accounted for $25 \%$ of new production, whereas the value was only $4 \%$ for phosphorus. Entrainment fluxes of nitrogen and phosphorus accounted for 27 and $43 \%$ of new production, respectively. This meant that $48 \%$ of the nitrogen and $53 \%$ of the phosphorus required for new production remained unaccounted for. In 1989 the contribution of both nitrogen and 
Table 3. Annual process rates resulting from spatial integration in the upper mixed layer for the entire Kattegat. All rates are in $\mathrm{gC} \mathrm{m}^{-2} \mathrm{yr}^{-1}$

\begin{tabular}{|c|c|c|c|c|c|c|c|c|c|c|}
\hline Process & 1989 & 1990 & 1991 & 1992 & $\begin{array}{l}\text { Year } \\
1993\end{array}$ & 1994 & 1995 & 1996 & 1997 & $\begin{array}{c}\text { Average for } \\
1989-1997\end{array}$ \\
\hline Primary production & 106 & 145 & 120 & 133 & 112 & 122 & 112 & 97 & 96 & $116 \pm 16$ \\
\hline Respiration & 12 & 16 & 14 & 13 & 13 & 18 & 15 & 11 & 14 & $14 \pm 2$ \\
\hline Net primary production & 94 & 129 & 106 & 120 & 99 & 104 & 97 & 86 & 82 & $102 \pm 15$ \\
\hline Sedimentation & 39 & 63 & 57 & 52 & 63 & 64 & 52 & 58 & 50 & $55 \pm 8$ \\
\hline Higher trophic levels & 18 & 22 & 16 & 23 & 12 & 13 & 15 & 9 & 11 & $15 \pm 5$ \\
\hline Regenerated production & 37 & 44 & 33 & 46 & 25 & 26 & 30 & 19 & 22 & $31 \pm 9$ \\
\hline New production & 57 & 85 & 73 & 74 & 75 & 77 & 67 & 68 & 61 & $71 \pm 9$ \\
\hline
\end{tabular}

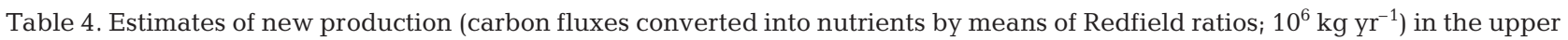
mixed layer compared to sources of nutrients for the Kattegat. Atmospheric deposition of phosphorus was not calculated. Land and atmospheric inputs are extracted from Hansen et al. (2000). Fluxes of nutrient-rich bottom water entrained into the upper mixed layer are from B. Gustafsson (unpubl. data). Other sources correspond to the input of nutrients required to balance the budgets

\begin{tabular}{|c|c|c|c|c|c|c|c|c|c|c|}
\hline & 1989 & 1990 & 1991 & 1992 & $\begin{array}{l}\text { Year } \\
1993\end{array}$ & 1994 & 1995 & 1996 & 1997 & $\begin{array}{c}\text { Average for } \\
1989-1997\end{array}$ \\
\hline \multicolumn{11}{|l|}{ Nitrogen } \\
\hline New production & 225 & 334 & 288 & 291 & 293 & 303 & 262 & 265 & 238 & $278 \pm 34$ \\
\hline Land and atmosphere & 60 & 77 & 69 & 77 & 72 & 95 & 71 & 48 & 55 & $69 \pm 14$ \\
\hline Entrainment flux & 115 & 124 & 86 & 59 & 82 & 78 & 59 & 29 & 32 & $74 \pm 33$ \\
\hline Other sources & 51 & 133 & 133 & 155 & 139 & 130 & 132 & 189 & 151 & $135 \pm 36$ \\
\hline \multicolumn{11}{|l|}{ Phosphorus } \\
\hline New production & 31.2 & 46.2 & 39.8 & 40.3 & 40.6 & 41.9 & 36.3 & 36.7 & 32.9 & $38.4 \pm 4.7$ \\
\hline Land & 1.8 & 1.8 & 1.5 & 1.3 & 1.3 & 1.9 & 1.4 & 0.8 & 1.0 & $1.4 \pm 0.4$ \\
\hline Entrainment flux & 26.3 & 28.5 & 22.7 & 14.3 & 15.9 & 14.7 & 12.0 & 9.1 & 6.5 & $16.7 \pm 7.6$ \\
\hline Other sources & 3.1 & 15.9 & 15.6 & 24.7 & 23.4 & 25.4 & 22.9 & 26.8 & 25.5 & $20.4 \pm 7.7$ \\
\hline
\end{tabular}

phosphorus from unaccounted sources (Table 4) was lower than that documented for the remainder of the 9 yr study period.

Annual new production was significantly related to nitrogen input from the land and atmosphere ( $p=0.0437$, F-test; Fig. 9), whereas the relationship to phosphorus input via these sources was not significant $(p=0.35, F$-test). The slope of the linear regression in
Fig. 9A indicates that a reduction of 1000 tonnes in $\mathrm{N}$ input per year corresponds to a reduction of $0.42( \pm 0.17) \mathrm{g} \mathrm{C} \mathrm{m}^{-2} \mathrm{yr}^{-1}$ in new production each year, which, in turn, corresponds to a decrease of $0.18 \mathrm{~g} \mathrm{C}$ $\mathrm{m}^{-2} \mathrm{yr}^{-1}$ in regenerated production (Table 3 ). Hence, a $50 \%$ reduction of the nitrogen derived from the land and atmosphere $\left(34.6 \times 10^{3}\right.$ tonnes $\left.\mathrm{N}\right)$ would be associated with an average reduction of 14 and $21 \mathrm{~g} \mathrm{C} \mathrm{m}^{-2} \mathrm{yr}^{-1}$
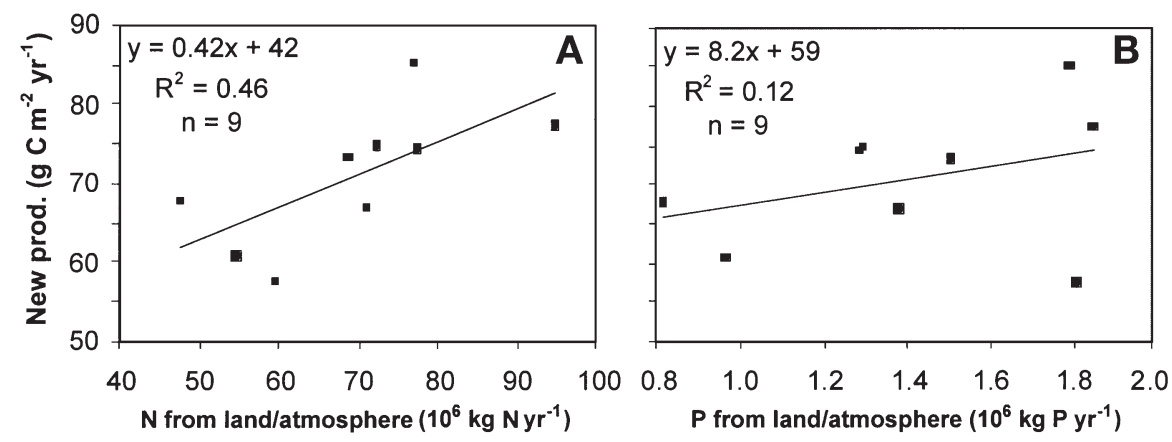

Fig. 9. Relationships between estimated annual new production in the upper mixed layer and (A) nitrogen input ( $\mathrm{p}=0.044, F$-test) and (B) phosphorus input from land and atmosphere $(\mathrm{p}=0.35, F$-test $)$ in new and net primary production, respectively, each year during the study period. This reduction would correspond to a $20 \%$ decrease in net primary production.

\section{DISCUSSION}

Hitherto, the most intensive investigations of carbon fluxes in the euphotic zone in the Kattegat were conducted in Laholm Bay (1981 to 1985) within the framework of the Swedish Research program 'Eutrophication in the Marine Environment' 
(Rosenberg et al. 1990) and in the southeastern Kattegat (1988-1990) under the Danish research program 'HAV90' (Christensen 1998). In Laholm Bay 1 station (depth $20 \mathrm{~m}$ ) was sampled approximately biweekly for 5 yr (Rydberg et al. 1990), providing data on primary production. In order to examine seasonal fluctuations in phytoplankton biomass, primary production (Richardson \& Christoffersen 1991) and sedimenting particulate matter levels (Olesen \& Lundsgaard 1995) in the southern Kattegat, 1 station (depth 29 m) was sampled approximately biweekly during the productive season for $3 \mathrm{yr}$, more frequently during the spring and autumn blooms, and less frequently during late autumn and winter. These earlier studies did not investigate spatial variations in carbon fluxes. Below we present a detailed comparison between these earlier single-station findings and the results of the present study which demonstrate large-scale trends in primary production rates and transfer pathways for the region as a whole during the period 1989 to 1997.

\section{Spatial distribution of primary production}

In our approach we used data from 13 stations and 9 yr. Spatial and, for that matter, temporal variations were substantial (24 to $37 \%$ variation between station rates averaged over the entire period, and 12 to $30 \%$ interannual variation for regional rates). These findings imply that caution should be adopted when extrapolating from single stations to an entire region. The relatively high level of resolution in the present study is probably even too coarse to adequately reflect smaller-scale fluctuations in the Kattegat, and the lack of stations along the Swedish coast may well have resulted in regional $\mathrm{C}$ and N/P fluxes having been slightly underestimated. Despite these strong spatiotemporal fluctuations, primary production rates in the coastal zone were consistently about twice the values recorded further offshore. Compared to the regional estimates, the high values at coastal stations show that the near-coast, shallow-water stations are not representative for the region as a whole. This implies that regional assessment of primary production should incorporate data from both coastal and open-water stations. However, the studies of Richardson \& Christoffersen (1991) and Heilmann et al. (1994) were located at open-water sites which were considered representative of the Kattegat as a whole. Evidently, regional variation in primary production cannot be assessed with the present DNAMAP, because 2 stations are insufficient to resolve the heterogeneous large-scale patterns in the Kattegat.

The external supply of nutrients from land and atmosphere was presumably higher for coastal stations, sustaining higher primary production levels due to (1) proximity to land-based sources of nutrients, (2) benthic-pelagic coupling and (3) upwelling. High rates along the North Zealand coast imply that primary production is less limited by nutrients and light here than off the Jutland coast. However, the North Zealand sector of the Kattegat does not have any major freshwater tributaries, as opposed to the Jutland coast, which receives substantial riverine loads from Gudenå and Limfjorden (Fig. 1). We hypothesise that upwelling of nutrients occurs along the North Zealand coast, caused by the south-flowing deep-water current. The reason why phytoplankton biomass was lower here (factor of 0.5 ) than along the Jutland coast remains unclear.

\section{Spring bloom}

The phytoplankton budget model showed seasonal variations in primary production similar to those found in earlier studies in the Kattegat (Rydberg et al. 1990, Richardson \& Christoffersen 1991, Heilmann et al. 1994). Most years had characteristic peaks in primary production during the spring period ( 1 to 3 spring blooms), but 1989 and 1997 were distinctively different, showing relatively low primary production during March to May. Richardson \& Christoffersen (1991) found a remarkably high primary production (3614 $\mathrm{mg} \mathrm{C} \mathrm{m}^{-2} \mathrm{~d}^{-1}$ ) in Week 13 in March 1989, when daily samples were taken in the southern Kattegat. This short-lived event was not evident in our primary production data for Stns 190004 and 20004 (although samples were taken within the same week) and, for that matter, for the other 11 stations too, most likely because the sampling intervals were too long (at least 1 to $2 \mathrm{wk}$ ) in the present case. Evidently, the former DNAMAP was not designed for optimal information on primary production during the dynamic and highly productive spring period. Thus, there is a strong inherent risk that the spring bloom peak will not appear in monitoring data based on such a biased sampling strategy.

According to Richardson \& Christoffersen (1991) $19 \%$ of the annual primary production in 1989 occurred in March to April during the 4 wk defined as their spring bloom, of which 1 wk (Week 13) contributed $9 \%$ to annual production. Rydberg et al. (1990) estimated the spring bloom of 1981 to 1985 (first 2 wk of March) to contribute on average $13 \%$ to annual production. We found that in 1993 Week 12 (in March) contributed 12\%, and in 1996 Week 10 (also in March) contributed $16 \%$ to annual production. Thus, the spring bloom contribution to annual production is on the order of 10 to $20 \%$ for the region, depending on the largely arbitrary choice of criteria to define such events. Evidently, insufficient documentation of spo- 
radic pulses in primary production, particularly in the spring, can substantially underestimate or overestimate annual production levels. By implication, the present-day DNAMAP, reduced to incorporate only 2 of the former 13 stations, should at least ensure more intensive sampling campaigns in spring.

\section{Annual primary production}

For the period 1975 to 1979, Ærtebjerg et al. (1981) found that annual primary production was highest in the southwestern part of the Kattegat, i.e. $122 \mathrm{~g} \mathrm{C} \mathrm{m}^{-2}$ $\mathrm{yr}^{-1}$, compared to $81 \mathrm{gC} \mathrm{m}^{-2} \mathrm{yr}^{-1}$ in the northeastern and $101 \mathrm{~g} \mathrm{C} \mathrm{m}^{-2} \mathrm{yr}^{-1}$ in the southeastern sectors. Rydberg et al. (1990) reported a value of $144 \mathrm{gC} \mathrm{m}^{-2} \mathrm{yr}^{-1}$ for Laholm Bay in 1981 to 1985. By contrast, Richardson \& Christoffersen (1991) found a higher production of $290 \mathrm{~g} \mathrm{C} \mathrm{m}^{-2} \mathrm{yr}^{-1}$ for their station in the southern Kattegat in 1989, and Heilmann et al. (1994) estimated annual production in the Skagerrak/Kattegat frontal region to have been approximately $190 \mathrm{~g} \mathrm{C} \mathrm{m}^{-2} \mathrm{yr}^{-1}$ in the period 1984 to 1993. We found $106 \mathrm{~g} \mathrm{C} \mathrm{m}^{-2} \mathrm{yr}^{-1}$ for 1989 for the Kattegat as a whole, and $116 \mathrm{~g} \mathrm{C} \mathrm{m}^{-2} \mathrm{yr}^{-1}$ as an average value for 1989 to 1997 . Our values correspond well with those reported by Ærtebjerg et al. (1981) and Rydberg et al. (1990), taking into account that Laholm Bay has a large freshwater input. The substantially higher annual production levels in Richardson \& Christoffersen (1991) and (albeit to a lesser extent) Heilmann et al. (1994) can have at least 4 nonalternative explanations.

(1) Richardson \& Christoffersen (1991) assessed carbon incorporation into both particulate (POC) and dissolved organic carbon, whereas all other studies, including the present one and, for that matter, Heilmann et al. (1994) and DNAMAP, considered POC fluxes only.

(2) Both Richardson \& Christoffersen (1991) and Heilmann et al. (1994) included subsurface chlorophyll peaks in their annual budgets, whereas the present study was restricted to the upper mixed layer ( 0 to $10 \mathrm{~m})$. Richardson \& Christoffersen (1991) estimated the contribution from subsurface production to be in the order of $30 \%$ of annual production. This means that annual budgets would have been underestimated at our 6 offshore stations ( $>15 \mathrm{~m}$ ) but not necessarily at our 7 shallower coastal stations, where a pycnocline may not have been present or any contribution from the pycnocline population may have been negligible. Nevertheless, approximately $90 \%$ of the surface area of the Kattegat has water depths exceeding $15 \mathrm{~m}$ (Gustafsson 2000), where subsurface production assessment would be essential for regional budgets to be at all realistic.
(3) Richardson \& Christoffersen (1991) carried out intensive sampling during the 1989 spring bloom, whereas the present study partly missed this event (see above), and perhaps more blooms in other years, too. Although the contribution from $1 \mathrm{wk}$ with a spring bloom can account for up to $16 \%$ of annual production, any error in annual primary production estimates of having missed such an event would be less ( $\sim 5$ to $10 \%)$.

(4) Compared to in spring and autumn, when primary production is highest in the Kattegat, Richardson \& Christoffersen (1991) conducted less intensive sampling in other seasons in 1989, particularly in late autumn, when the sampling interval twice reached $7 \mathrm{wk}$. All data points were interpolated linearly in time and aggregated, a method which can produce overestimates of total annual production, because the data would have been strongly skewed towards higher production levels, whereas linear interpolation tends to produce values equally distributed over the whole range of observations. We estimate that this artefact may have overestimated annual production by $10 \%$ in the study of Richardson \& Christoffersen (1991). We also applied linear interpolation for weeks without data, but these gaps between observations were fewer, smaller and largely restricted to mid-winter, when production is essentially always low.

In view of these considerations, the annual primary production estimated from the DNAMAP data in the present study is consistent with the estimates of Richardson \& Christoffersen (1991) and Heilmann et al. (1994). We estimated that the average annual production for the study period would have been approximately $35 \%$ higher $\left(157 \mathrm{~g} \mathrm{C} \mathrm{m}^{-2} \mathrm{yr}^{-1}\right)$ if subsurface production had been accounted for and if more intensive monitoring had been conducted during all spring bloom periods. Interannual variation in the annual production estimates $( \pm 14 \%)$ was considerable lower than variation between stations $( \pm 28 \%)$. Thus, it is more important to consider the choice of stations than the choice of years for generating regional production estimates.

\section{Relative respiration loss}

According to the trophic classification system in Nixon (1995), the Kattegat can be considered as mesotrophic. Net primary production was approximately $88 \%$ of total annual production in the present study, and respiration accounted for the remaining $12 \%$. The fraction of total annual primary production used for respiration was comparable to those reported in other studies (e.g. 15\% in Richardson 1996). This 
justified the model assumption of $50 \%$ respiration loss in winter, although the quantification of the carbon budgets was not highly sensitive to this assumption (relatively small respiration rates).

The finding that relative respiration loss, defined as the fraction of measured primary production used for respiration, was related to water depth could be viewed as a model artefact which resulted in relatively higher respiration rates at shallow-water stations. However, respiration depends only on measured $P_{\max }$ and seasonal variations in light, and the average ratio between measured primary production and $P_{\max }$ for the 13 stations reflected the same depth dependency. Thus, the same general pattern-the phytoplankton community at open-water stations is more efficient in production, the reverse being the case at shallowwater stations - was true for observed data as well as for the model calculations.

Light limitation was the important factor giving rise to this general pattern. In our model, respiration at any given time of the year is proportional to $P_{\max }$ only, and the relative respiration loss depends inversely on the fraction of $P_{\max }$ reached by photosynthesis and therefore reflects the light saturation of phytoplankton. Thus, relative respiration loss could vary due to (1) differences in water transparency and (2) differences in the depth distribution of the phytoplankton population. We evaluated measurements of water transparency (data not shown) during the productive season and found a weak negative correlation between relative respiration loss and transparency ( $\mathrm{r}=-0.30, F$-test, $\mathrm{p}=0.32, \mathrm{n}=13$ ). However, this negative relationship resulted from a single observation, and it is therefore unlikely that differences in water transparency could explain variations in relative respiration loss in the present case. If the phytoplankton community had shown deeper distributions at shallow-water stations, then primary production would have been more light limited due to the natural extinction of light, and respiration losses would have been relatively large. We evaluated measurements of chl a sampled at various depths for 10 of the 13 stations (data not shown) and calculated ratios between average concentrations below and above $5 \mathrm{~m}$ depth. A negative relationship between this ratio and water depth $(\mathrm{r}=-0.47, F$-test, $\mathrm{p}=0.17, \mathrm{n}=10$ ) and a positive relationship between this ratio and relative respiration loss $(\mathrm{r}=0.51, F$-test, $\mathrm{p}=0.13, \mathrm{n}=10$ ) indicated that at shallow-water stations phytoplankton was distributed at greater depths than at openwater stations, resulting in a higher relative respiration loss in the former. Thus, we contend that the relatively larger respiration loss at shallow-water stations was due to a larger fraction of the phytoplankton community being light limited.

\section{Sedimentation}

In the present study seasonal variations in estimated sedimentation rates resembled the phytoplankton carbon fluxes reported in Olesen \& Lundsgaard (1995) for the year 1989, being primarily dominated by spring blooms and, to a lesser extent, by autumn blooms. Thus, it appears that, in general, more than half of the phytoplankton biomass sedimenting from the upper mixed layer each year does so during the spring months. Olesen \& Lundsgaard (1995) also analysed seasonal variations in total POC fluxes and found an annual sedimentation of $63 \mathrm{~g} \mathrm{C} \mathrm{m}^{-2} \mathrm{yr}^{-1}$ with a less pronounced seasonal pattern, whereas annual sedimentation of viable phytoplankton cells was only ca $11 \mathrm{~g} \mathrm{C} \mathrm{m}^{-2} \mathrm{yr}^{-1}$. In 1989 we estimated a sedimentation rate of $39 \mathrm{~g} \mathrm{C} \mathrm{m}^{-2} \mathrm{yr}^{-1}$ for all phytoplankton (1989 to 1997 averaged $55 \mathrm{~g} \mathrm{C} \mathrm{m}^{-2}$ $\left.\mathrm{yr}^{-1}\right)$, a value intermediate to those recorded for POC and phytoplankton carbon fluxes by Olesen \& Lundsgaard (1995). Seeing that POC sedimentation was largely in the form of detritus in the study by Olesen \& Lundsgaard (1995), we should compare our estimates with their viable phytoplankton carbon fluxes. However, there are at least 2 important aspects which argue against the validity of such a direct comparison.

(1) Olesen \& Lundsgaard (1995) calculated annual sedimentation fluxes on the basis of measurements from sediment traps in March to October 1989. Measurements were not carried out in winter, due to high resuspension of organic material from the bottom (C. Lundsgaard pers. comm.), and sedimentation over the winter period was assumed to be negligible. By contrast, sedimentation in November to February accounted for up to $14 \%$ of annual sedimentation fluxes at the 13 stations in the present study. Most of this material resulted from the formation and subsequent sedimentation of minor blooms documented in January-February. Thus, sedimentation of winter blooms can contribute measurably to annual sedimentation fluxes at times.

(2) Olesen \& Lundsgaard (1995) determined phytoplankton carbon fluxes from measurements of chl $a$ in sediment traps, and from $\mathrm{C} / \mathrm{chl}$ a ratios determined in water samples from the upper mixed layer. The traps were deployed for $24 \mathrm{~h}$ at a stretch and, if chl a had been degraded during deployment, phytoplankton carbon fluxes would have been underestimated. Chl a can degrade also while sedimenting out of the upper mixed layer (Reigstad et al. 2000). Thus, we suspect that using $\mathrm{C} / \mathrm{chl}$ a ratios could have underestimated phytoplankton carbon sedimentation in the study of Olesen \& Lundsgaard (1995).

Olesen \& Lundsgaard (1995) found that the POC/ PON ratio in sedimenting material was much higher than that recorded in the upper mixed layer and pro- 
posed that $\mathrm{N}$ was quickly assimilated by autotrophs in the upper mixed layer. In their budget calculations they found that external input of $\mathrm{N}$ to the euphotic zone could support a new production of $42 \mathrm{~g} \mathrm{C} \mathrm{m}^{-2} \mathrm{yr}^{-1}$, and that the faster recycling of $\mathrm{N}$ could support an additional 14 to $15 \mathrm{gC} \mathrm{m}^{-2} \mathrm{yr}^{-1}$ - production which is considered new with respect to carbon but regenerated with respect to nitrogen (Olesen \& Lundsgaard 1995). Combining these 2 estimates yields a value which corresponds well with our estimate of new production $\left(71 \mathrm{~g} \mathrm{C} \mathrm{m}^{-2} \mathrm{yr}^{-1}\right)$. Thus, the faster recycling of $\mathrm{N}$ and also $\mathrm{P}$ could explain the imbalance of the nitrogen and phosphorus budgets documented in the present study $\left(135 \times 10^{6} \mathrm{~kg} \mathrm{~N} \mathrm{yr}^{-1}\right.$ and $\left.20.4 \times 10^{6} \mathrm{~kg} \mathrm{P} \mathrm{yr}^{-1}\right)$. If we assume that other sources of nutrients derived from the fast recycling of nutrients, then $34 \mathrm{~g} \mathrm{C} \mathrm{m}^{-2} \mathrm{yr}^{-1}$ (48\%) of new production (average for all years) can be considered regenerated in terms of $\mathrm{N}$ and $\mathrm{P}$, and $74 \%$ of the annual net production to be regenerated.

\section{Nutrient input and primary production}

Nixon et al. (1995) assessed relationships between external dissolved nitrogen input and primary production rates in a variety of marine systems. Applying their relationship to our estimates of external total $\mathrm{N}$ input via land and atmosphere revealed an expected annual primary production of $152 \mathrm{gC} \mathrm{m}^{-2} \mathrm{yr}^{-1}$, which is in accordance with the estimates given above. We quantified the relationship between external nitrogen input and new production, and we found that a $50 \%$ reduction in nitrogen inputs corresponds to a $20 \%$ reduction in net primary production in the Kattegat. The finding that new production was significantly related only to nitrogen inputs is consistent with the general conception of the Kattegat being nitrogen limited (Granéli 1987, Granéli et al. 1990).

If other nitrogen sources derived from fast recycling of $\mathrm{N}$, then regenerated and new production would have been 68 and $34 \mathrm{gC} \mathrm{m}^{-2} \mathrm{yr}^{-1}$, respectively. In this case, net primary production would have been reduced by $42 \%$ from a $50 \%$ reduction in nitrogen inputs. Indeed, it is likely that the effect of a reduction in nitrogen input would be even larger, because this should over time lower the inorganic nitrogen concentration in the bottom water and consequently reduce the nitrogen entrainment flux. Thus, a 50\% reduction in nitrogen input should reduce net primary production by at least 20 to $42 \%$. However, Richardson \& Heilmann (1994) reported a 2- to 3-fold increase in primary production since the 1950s. It is therefore unlikely that a $50 \%$ reduction in nitrogen loads will be sufficient to restore the levels of primary production recorded more than 50 yr ago in the Kattegat.
Acknowledgements. Funding for this project was provided by the Nordic Council of Ministers (Nordic working group for monitoring and data analysis). B. Gustafsson calculated nutrient entrainment fluxes for Kattegat, and we greatly appreciate his contribution. We thank G. Ærtebjerg, S. Markager and T. G. Nielsen for valuable discussions during the modelling phase and for commenting on the manuscript. We express our sincere thanks to the persons and institutions which have laboured to collect the data used in this study. The manuscript was greatly improved with the comments from 2 anonymous referees.

\section{LITERATURE CITED}

Ærtebjerg G, Jacobsen T, Gargas E, Buch E (1981) The Belt Project: evaluation of the physical, chemical and biological measurements. Danish Environmental Protection Agency, Copenhagen

Andersson L (1996) Trends in nutrient and oxygen concentrations on the Skagerrak-Kattegat. J Sea Res 35:63-71

Andersson L, Rydberg L (1988) Trends in nutrient and oxygen conditions within the Kattegat: Effects of local nutrient supply. Estuar Coast Shelf Sci 26:559-579

Antoine D, Morel A (1996) Oceanic primary production1. Adaption of a spectral light-photosynthesis model in view of application to satellite chlorophyll observations. Global Biogeochem Cycles 10:43-55

Arístegui J, Montero MF, Ballesteros S, Basterretxea G, van Lenning K (1996) Planktonic primary production and microbial respiration measured by ${ }^{14} \mathrm{C}$ assimilation and dissolved oxygen changes in coastal waters of the Antarctic Peninsula during austral summer: implications for carbon flux studies. Mar Ecol Prog Ser 132:191-201

Bury SJ, Boyd PW, Preston T, Savidge G, Owens NJP (2001) Size-fractionated primary production and nitrogen uptake during a North Atlantic phytoplankton bloom: implications for carbon export estimates. Deep-Sea Res I 48: $689-720$

Chatfield C (1984) The analysis of time series: an introduction. Chapman \& Hall, London

Christensen PB (ed) (1998) The Danish marine environment: has action improved its state? Marine research programme HAV90. Havforskning fra Miljøstyrelsen Nr 62. Danish Environmental Protection Agency, Copenhagen

Cole JJ, Caraco NF, Peierls B (1991) Phytoplankton primary production in the tidal freshwater Hudson River, New York (USA). Vehr Int Ver Limnol 24:1715-1719

Cressie NAC (1993) Statistics for spatial data. Wiley, New York

Dring MJ, Jewson DH (1982) What does ${ }^{14}$ C uptake by phytoplankton really measure? A theoretical modelling approach. Proc R Soc Lond B 214:351-368

Falkowski PG, Flagg CN, Rowe GT, Smith SL, Whitledge JE, Wirick CD (1988) The fate of a spring phytoplankton bloom: export or oxidation? Cont Shelf Res 8:457-484

Fischer G, Ratmeyer V, Wefer G (2000) Organic carbon fluxes in the Atlantic and the Southern Ocean: relationship to primary production compiled from satellite radiometer data. Deep-Sea Res II 47:1961-1997

Granéli E (1987) Nutrient limitation of phytoplankton biomass in a brackish water bay highly influenced by river discharge. Estuar Coast Shelf Sci 25:563-569

Granéli E, Wallström K, Larsson U, Granéli W, Elmgren R (1990) Nutrient limitation of primary production in the Baltic Sea area. Ambio 19:142-151

Gustafsson B (2000) Time-dependent modeling of the Baltic 
entrance area. 1. Quantification of circulation and residence times in the Kattegat and the straits of the Baltic sill. Estuaries 23:231-252

Hansen JLS, Pedersen B, Carstensen J, Conley D and 19 others (2000) Marine waters: Environmental state in 1999 (in Danish). Report No. 333. National Environmental Research Institute, Roskilde

Hansen PJ, Bjørnsen PK, Hansen BW (1997) Zooplankton grazing and growth: scaling within the $2-2,000 \mu \mathrm{m}$ body size range. Limnol Oceanogr 42:687-704

Heilmann JP, Richardson K, Ærtebjerg G (1994) Annual distribution and activity of phytoplankton in the Skagerrak/ Kattegat frontal region. Mar Ecol Prog Ser 112:213-223

HELCOM (2001) Manual for marine monitoring in the combine programme of HELCOM. HELCOM MONAS 3/2001, Helsinki Commission (www.helcom.fi), Helsinki

Howarth RW, Schneider R, Swaney D (1996). Metabolism and organic carbon fluxes in the freshwater Hudson River. Estuaries 19:848-865

Huntley ME, Lopez MDG (1992) Temperature dependent production of marine copepods: a global synthesis. Am Nat 140:201-242

Iverson RL (1990) Control of marine fish production. Limnol Oceanogr 35:1593-1604

Jackson GA (2001) Effect of coagulation on a model planktonic food web. Deep-Sea Res I 48:95-123

Jakobsen F (1997) Hydrographic investigation of the Northern Kattegat front. Cont Shelf Res 17:533-554

Kemp WM, Smith EM, Marvin-DiPasquale M, Boynton WR (1997) Organic carbon balance and net ecosystem metabolism in Chesapeake Bay. Mar Ecol Prog Ser 150:229-248

Kiørboe T (1996) Material flux in the water column. In: Jørgensen BB, Richardson K (eds) Coastal marine eutrophication. American Geophysical Union, Washington, DC, p 67-94

Koeve W (2001) Wintertime nutrients in the North Atlanticnew approaches and implications for new production estimates. Mar Chem 74:245-260

Kronvang B, Ertebjerg G, Grant R, Kristensen P, Hovmand M, Kirkegaard J (1993) Nationwide monitoring of nutrients and their ecological effects: state of the Danish aquatic environment. Ambio 22:176-187

Langdon C (1993) The significance of respiration in production measurements based on oxygen. ICES Mar Sci Symp 197:69-78

Lundsgaard C, Olesen M (1997) The origin of sedimenting detrital matter in a coastal system. Limnol Oceanogr 42: 1001-1005

McCullagh P, Nelder JA (1989) Generalized linear models, 2nd edn. Chapman \& Hall/CRC, Boca Raton, FL

Nielsen TG, Kiørboe T (1991) Effects of a storm event on the structure of the pelagic food web with special emphasis on planktonic ciliates. J Plankton Res 13:35-51

Nixon SW (1995) Coastal marine eutrophication: a definition, social causes and future concerns. Ophelia 41:199-219

Nixon SW, Ammerman JW, Atkinson LP, Berounsky VM and 12 others (1995) The fate of nitrogen and phosphorus at the land-sea margin of the North Atlantic Ocean. Biogeochemistry 35:141-180

Editorial responsibility: Victor de Jonge (Contributing Editor), Haren, The Netherlands
Olesen M, Lundsgaard C (1995) Seasonal sedimentation of autochthonous material from the euphotic zone of a coastal system. Estuar Coast Shelf Sci 41:475-490

Peterson BJ (1978) Radiocarbon uptake: its relation to net particulate carbon production. Limnol Oceanogr 23:179-184

Redfield AC (1958) The biological control of chemical factors in the environment. Am Sci 46:205-222

Reigstad M, Wassmann P, Ratkova T, Arashkevich E, Pasternak A, Øygarden S (2000) Comparison of the springtime vertical export of biogenic matter in three northern Norwegian fjords. Mar Ecol Prog Ser 201:73-89

Richardson K (1985) Plankton distribution and activity in the North Sea/Skagerrak-Kattegat frontal area in April 1984. Mar Ecol Prog Ser 26:233-244

Richardson K (1996) Carbon flow in the water column. In: Jørgensen BB, Richardson K (eds) Eutrophication in coastal marine systems. American Geophysical Union, Washington, DC, p 95-114

Richardson K, Christoffersen A (1991) Seasonal distribution and production of phytoplankton in the southern Kattegat. Mar Ecol Prog Ser 78:217-227

Richardson K, Heilmann JP (1995) Primary production in the Kattegat past and present. Ophelia 41:317-328

Rosenberg R, Elmgren R, Fleischer S, Jonsson P, Persson G, Dahlin H (1990) Marine eutrophication case studies in Sweden. Ambio 19:102-108

Rosenberg R, Loo LO, Möller P (1992) Hypoxia, salinity and temperature as structuring factors for marine benthic communities in a eutrophic area. Neth J Sea Res 30:121-129

Rydberg L, Edler L, Floderus S, Granéli W (1990) Interaction between supply of nutrients, primary production, sedimentation and oxygen consumption. Ambio 19:134-141

Sand-Jensen K, Nielsen SL, Borum J, Geertz-Hansen O (1994) Phytoplankton and macrophyte development in the Danish coastal zone. Havforskning fra Miljøstyrelsen Nr 30, Danish Environmental Protection Agency, Copenhagen

Sehested Hansen I, Ærtebjerg G, Richardson K (1995) A scenario analysis of reduced nitrogen input on oxygen conditions in the Kattegat and the Belt Sea. Ophelia 42:75-93

Smith SV, Hollibaugh JT (1997) Annual cycle and interannual variability of ecosystem metabolism in a temperate climate embayment. Ecol Monogr 67:509-533

Steemann Nielsen E (1952) The use of radio-active carbon $\left(\mathrm{C}^{14}\right)$ for measuring organic production in the sea. J Cons Int Explor Mer 18:117-140

Strathman RR (1967) Estimating the organic carbon content of phytoplankton from cell volume or plasma volume. Limnol Oceanogr 12:411-418

Walsh JJ, Dieterle DA, Lenes J (2001) A numerical analysis of carbon dynamics of the Southern Ocean phytoplankton community: the roles of light and grazing in effecting both sequestration of atmospheric $\mathrm{CO}_{2}$ and food availability to larval krill. Deep-Sea Res 48:1-48

Wassmann P (1991) Dynamics of primary production and sedimentation in shallow fjords and polls of western Norway. Oceanogr Mar Biol Annu Rev 29:87-154

Wefer G, Fischer G (1991) Annual primary production and export flux in the Southern-Ocean from sediment trap data. Mar Chem 35:597-613

Submitted: October 17, 2001; Accepted: November 18, 2002 Proofs received from author(s): March 27, 2003 